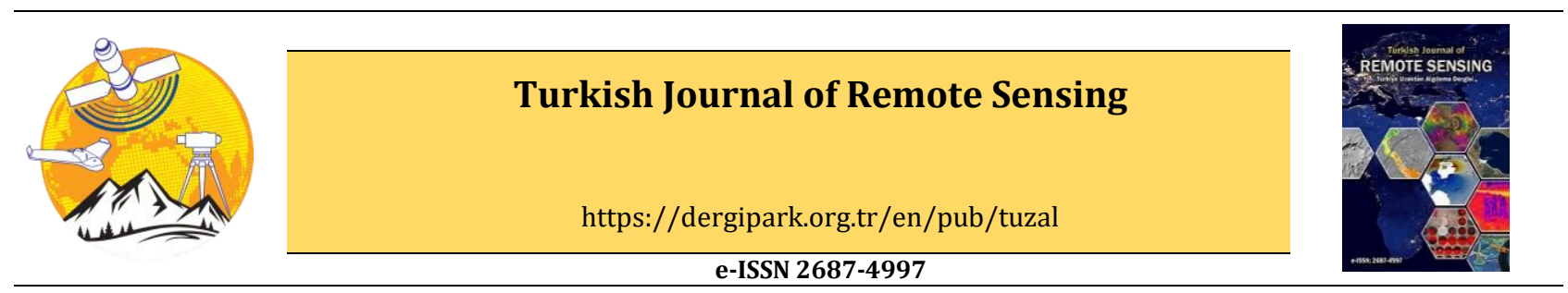

\title{
Bathymetry analysis with use of Sentinel-2 images
}

\author{
Hakan Uzakara*1(D), Nusret Demir 1 (D) \\ ${ }^{1}$ Akdeniz University, Faculty of Science, Department of Space Sciences and Technologies, Antalya, Turkey
}

\author{
Keywords \\ Remote sensing \\ Bathymetry \\ LIDAR \\ Sentinel-2
}

\begin{abstract}
Bathymetry is described as Sea and Ocean depth measurements, and performed by many methods. Traditional methods, which are still used from the past to the present, have been replaced by modern methods with the development of technology. Sonar systems, LIDAR and remote sensing systems are listed as examples of these modern methods. The use of acoustic systems or LIDAR, are not economical in terms of both time and cost. In this study, remote sensing methods are investigated in order to minimize the time and cost. It is aimed to extract the information about bathymetry with use of free of charge satellite images. The method data used includes Sentinel-2 satellite images taken at different wavelengths and reference bathymetry values. Later, regression analyzes were made by using these data in band ratio and multi-band methods. By using the coefficients obtained by the regression analysis, the bathymetry estimation was made in places with unknown depth using the above methods without the need for reference depth.Band ratio and multi-band methods are used, and the results were evaluated. Bathymetric maps obtained from two methods were analyzed with the ground-truth values of the region and the amount of error was calculated. The highest accuracy was obtained from the ratio of blue band to green band. It has been observed that the red band has a disruptive effect.
\end{abstract}

\section{Sentinel-2 görüntülerinin kullanımıyla batimetri analizi}

\author{
Anahtar Kelimeler: \\ Uzaktan Algılama \\ Batimetri \\ LIDAR \\ Sentinel-2
}

\begin{abstract}
ÖZ
Batimetri, Deniz ve Okyanus derinlik ölçümleri olarak tanımlanmakta ve birçok yöntemle yapılmaktadır. Geçmişten günümüze kadar hala kullanılan geleneksel yöntemler, teknolojinin gelişmesiyle yerini modern yöntemlere bırakmıștır. Sonar sistemleri, LIDAR ve uzaktan algllama sistemleri bu modern yöntemlerin örnekleri olarak listelenmiştir. Akustik sistemlerin veya LIDAR'ın kullanımı hem zaman hem de maliyet açısından ekonomik değildir. Bu çalışmada zaman ve maliyeti en aza indirmek için uzaktan algılama yöntemleri araştırılmıştır. Batimetri ile ilgili bilgilerin ücretsiz uydu görüntüleri kullanılarak çıkarılması amaçlanmaktadır. Kullanılan yöntem verileri, farklı dalga boylarında alınan Sentinel-2 uydu görüntülerini ve referans batimetri değerlerini içerir. Daha sonra bu veriler bant oranı ve çok bantlı yöntemlerde kullanılarak regresyon analizleri yapılmıștır. Regresyon analizi ile elde edilen katsayılar ile, referans derinliğe ihtiyaç duyulmadan derinliği bilinmeyen yerlerde yukarıdaki yöntemler kullanılarak batimetri tahmini yapılmıştır. Bant oranı ve çok bantlı yöntemler kullanılmış ve sonuçlar değerlendirilmiştir. Her iki yöntemden elde edilen batimetrik haritalar bölgenin gerçek derinlik değerleri ile analiz edilmiş ve hata miktarı hesaplanmıștır. En yüksek doğruluk, mavi bandın yeșil banda oranından elde edilmiștir. Kırmızı bandın bozucu bir etkiye sahip olduğu görülmüştür.
\end{abstract}




\section{INTRODUCTION}

Remote sensing is a science that provides information about the natural and artificial objects of the earth and evaluates them, without physical contact with the objects by using several platforms including satellites. It provides fast and economical solutions for many cases including land use, agriculture and marine studies etc.

Correct and up-to-date coastal bathymetry is a basic requirement in sea and ocean studies. Climate changes and environmental impacts significantly affect coastal areas. Bathymetry data are of great importance in developing models that can predict these effects (Misra \& Ramakrishnan, 2020). In the literature, bathymetry are obtained from sonar devices, lidar data and satellite images. Sonar system and LIDAR are active remote sensing systems that measure marine topography and physical properties with sound waves and laser light, respectively. High resolution bathymetric maps can be produced using returning pulses (Brock et al., 2004; Dartnell \& Gardner, 2004). Sonar systems, are widely used in marine ecosystem mapping in shallow and deep water and bathymetric mapping of the sea floor (Wilson et al., 2006). However, since sonar systems are generally ship-based, they cannot collect data in areas less shallow than 15 meters. LIDAR systems are more suitable for mapping these shallow environments (Costa et al., 2009). Although Dronebased LIDAR and camera systems are capable of producing high resolution bathymetric maps, they only allow spatial analysis of small areas due to technical limitations. In case of need for repeated onsite measurements for temporal monitoring and evaluation of the coastal zone with the abovementioned sonar and LIDAR systems, logistical difficulties are encountered (Misra \& Ramakrishnan, 2020). To overcome the difficulties and disadvantages of these traditional methods, satellitebased remote sensing techniques have been developed (Pacheco et al., 2015). Although satellitederived bathymetry does not have sonar or lidar accuracy, its large field capability, low cost and allowing analysis for areas where are not contacted easily (Gao, 2009).

Bathymetry algorithms derived from optical satellite images are generally derived from physicsbased and empirical models. Empirical models are more commonly used. Physics-based models explain the physics of the light with the water surface, water column and bottom and do not need points of known depth for calibration (Maritorena et al., 1994; Lee et al., 1999; Brando et al., 2009; Kerr \& Purkis, 2018). Empirical models make depth estimates with regression analysis. For this, it uses reference points whose depth is known, and relates the reflection with depth. (Philpot, 1989). It is basically based on the relationship between reflected energy and water depth. For each pixel of the satellite image, there is a statistical relationship between the amount of energy detected by the sensor and the depth of the water at that pixel location. This relationship can be analyzed using various calculation algorithms for bathymetry analysis (Kumari \& Ramesh, 2020). Most of these algorithms require reference points which include about the depth (Jawak \& Luis, 2015). When physics-based models and empirical models are compared in the derivation of bathymetry, empirical models are more advantageous due to their easier and faster results (Liu et al., 2015).

Satellite images have different spatial resolution (+100 m - $31 \mathrm{~cm})$. Only images with a resolution higher than $30 \mathrm{~m}$ are suitable since bathymetry derived from satellite images are based on average depth per pixel (Bailly du Bois, 2011). High resolution (less than a few meters) satellites such as WorldVIEW-2 and RapidEye for deriving bathymetry from satellite images, medium resolution (10 - $30 \mathrm{~m})$ satellites such as Landsat-8 and Sentinel-2, 3 are increasingly being tested for bathymetry analysis of shallow regions (Caballero \& Stumpf 2019; Stumpf et al. 2003). The spatial and spectral resolution of satellite images used in bathymetry analyzes, satellite viewing angle, atmospheric effects, tidal level, sunlight and vegetation affect the accuracy. Some of these effects can be overcome by preciese selection of satellite images and image processing (Kumari \& Ramesh 2020). In this study, bathymetry analysis was performed with free use of Sentinel-2 images which are freely available thorugh ESA Copernicus program.

\section{METHOD}

\subsection{Study Area}

The study area has been selected from the coastal zone of the city of Los Angeles in the state of California, USA.

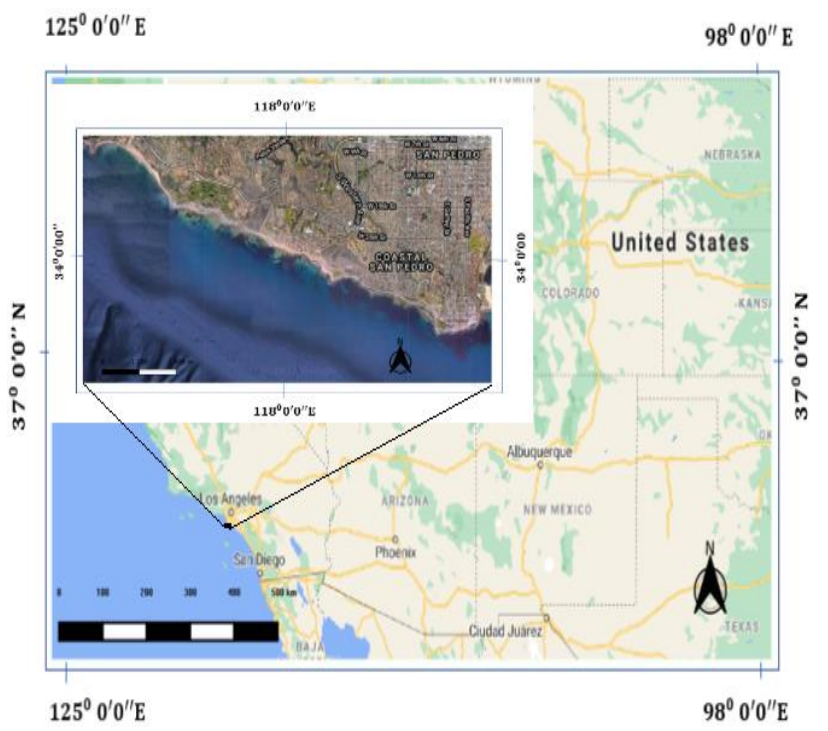

Figure 1. Study area 
A preliminary analysis process was carried out to evaluate the water quality of the study area. Green normalized difference vegetation index (GNDVI) was used for this procedure. Equation 1 shows the GNDVI formula.

GNDVI $=\frac{(N I R-G R E E N)}{(N I R+G R E E N)}$

GNDVI normalized difference vegetation index (NDVI) is a similar method. GNDVI values take values between -1 and 1 . Values above 0.1 indicate the presence of vegetation and values below zero indicate water (Ma et al., 2007). GNDVI is five times more sensitive to chlorophyll than NDVI (Gitelson et al., 1996).

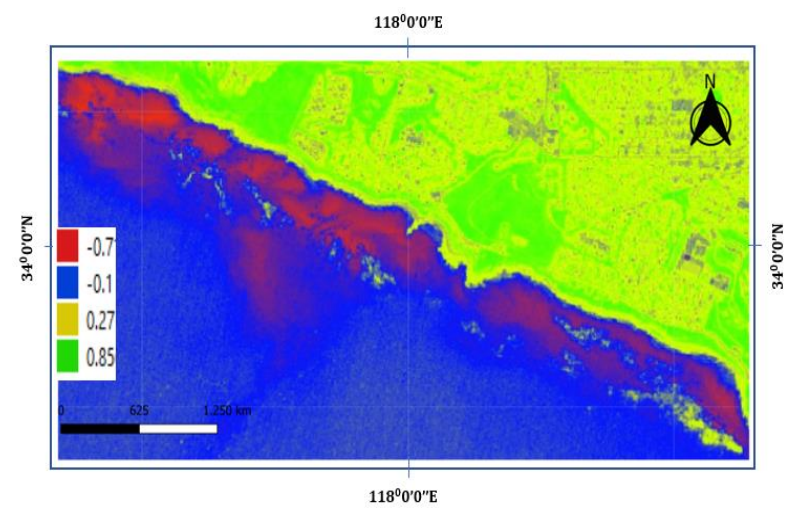

Figure 2. Computed color GNDVI image of the working area.

Looking at the figure above, it is an indication of the presence of green and yellow tones of chlorophyll in the parts near the shore. Red areas indicate that the water is cloudy or that the water quality is poor. Since these cause deviations in spectral reflections, regions with a depth of 10 meters to 30 meters were chosen as the study area.

\subsection{Materials}

Sentinel-2 satellites are part of the European Space Agency Copernicus profile. Two twin satellites (A / B) contain multi spectral images (MSI) with 10, 20 and $30 \mathrm{~m}$ spatial resolution. Sentinel-2 MSI is a polar-orbit, multi-band, high resolution, 5-day spatial resolution twin satellite system that aims to perform field analyzes such as vegetation, soil and water cover areas. Atmospheric effects are present in Sentinel-2 Level-1C products. Since March 2018, the atmospheric effects of Level-2A products derived from Level-1C products have been presented to the public in a corrected manner. Sentinel-2A became operational on June 23, 2015 and Sentinel 2B on March 7, 2017. (Agency, European Space, 2015). Sentinel-2B level $1 \mathrm{C}$ satellite images of the study area dated 30/03/2019 were downloaded from Scientific Data Hub. The spectral and spatial properties of the bands used in the study are shown below. In order to eliminate atmospheric effects, atmospheric correction was applied on the images with the QGIS program.

Table 1. Sentinel-2 satellite band features

\begin{tabular}{llll}
\hline Band & Name & $\begin{array}{l}\text { Central } \\
\text { wavelength } \\
\text { (nm) }\end{array}$ & $\begin{array}{l}\text { Spatial } \\
\text { resolution } \\
\text { (m) }\end{array}$ \\
\hline 1 & Aerossol & 443 & 60 \\
2 & Blue & 490 & 10 \\
3 & Green & 560 & 10 \\
4 & Red & 665 & 10 \\
5 & Red Edge 1 & 705 & 20 \\
6 & Red Edge 2 & 740 & 20 \\
7 & Red Edge 3 & 783 & 20 \\
8 & NIR & 842 & 10 \\
9 & Cirrus & 945 & 60 \\
10 & SWIR 1 & 1380 & 60 \\
11 & SWIR2 & 1610 & 20 \\
12 & Red Edge 4 & 2190 & 20 \\
\hline
\end{tabular}

Reference bathymetry data of the analysis area was obtained from TCarta Global Bathymetry GIS Data site at $10 \mathrm{~m}$ resolution. Bathymetry data belong to the date of 27/09/2017 and satellite images were chosen as the closest date to bathymetry acquisition data depending on weather conditions.

\subsection{Method}

The analysis is directly dependent on solar radiation. Absorption, scattering and reflection occur when solar radiation reaches the water surface. The energy of the light entering the water body will be reflected from the base and reach the sensor. Depth estimation can be made as a function of light reflected from underwater using bands of different wavelengths. Depth was estimated using different band combinations in the study. Different combinations were obtained by using blue, green and red spectral bands. The interaction of each band with the water column has different reflection properties, which is an important factor in improving accuracy in depth estimation.

\subsubsection{Dual Band Ratio Method}

The bottom reflectance of the two bands does not change with the type of substrate. This can eliminate the influence of water type and the ratio of the two bands can be used to calculate water depth (Chen et al., 2019; Bramante et al., 2012).

$Z=m_{0} * \frac{\ln \left(n R_{w}(\lambda i)\right)}{\ln \left(n R_{w}(\lambda j)\right)}-m_{1}$

Equation $2 \lambda \mathrm{i}$ and $\lambda \mathrm{j}$ are the reflection values of the bands. For the equation to be positive in all conditions, $\mathrm{n}$ is a constant number. The reference bathymetric depths will be written instead of $\mathrm{z}$ and the $\mathrm{m} 1$ and $\mathrm{m} 0$ coefficients will be found. By using the coefficients found, a depth estimation is aimed 
for areas of unknown depth. This method is based on the absorption of each tape into a different body of water. These different absorptions create a ratio between the bands. These rates theoretically increase as the depth increases.

\subsubsection{Multi Band Method}

The multi-band model represents more than one aspect of water depth (Stumpf et al., 2003). Z reference depth values, spectral reflection values of the $R_{n} \mathrm{n}$ band, a are indeterminate coefficients.

$$
Z=a_{0}+a_{1} \ln \left(R_{1}\right)+a_{2} \ln \left(R_{2}\right)+\ldots .+a_{n} \ln \left(R_{n}\right)
$$

The above equation calculates unknown coefficients $a_{n}$ by multiple regression analysis, using $R_{n}$ bands against reference depth values.

\subsubsection{Accuracy Evaluation}

The results obtained from both models were evaluated with absolute error $\left(D_{a}\right)$, relative error $\left(D_{b}\right)$ and RMSE $\left(D_{c}\right)$.

$D_{a}=\frac{\left|z_{1}-z_{2}\right|}{n}$

$D_{b}=\frac{\sum_{1}^{n}\left|\frac{z_{1}-z_{2}}{z_{1}}\right|}{n}$

$D_{c}=\sqrt{\frac{\sum_{1}^{n}\left(z_{1}-z_{2}\right)^{2}}{n}}$

$z_{1}$ represents the actual depth value, $z_{2}$ represents the calculated depth value $\mathrm{n}$ and the sample size.

\section{RESULTS}

Correlation analysis was performed between reference bathymetry values and band combinations to determine the most appropriate method and band combination. Table 2 below shows the calculated correlation coefficients.

In the multi-band model, the best correlation was obtained with the combination of blue, green and red bands. In the double band ratio model, the lowest is obtained from the ratio of blue band to green band. In general, it is seen that the correlation coefficients are significant. Equation 2 regression analysis and Equation 3. As a result of multiple regression analysis, the depth estimation of the analysis area was made by calculating the $\mathrm{m}$ and $\mathrm{a}$ coefficient.

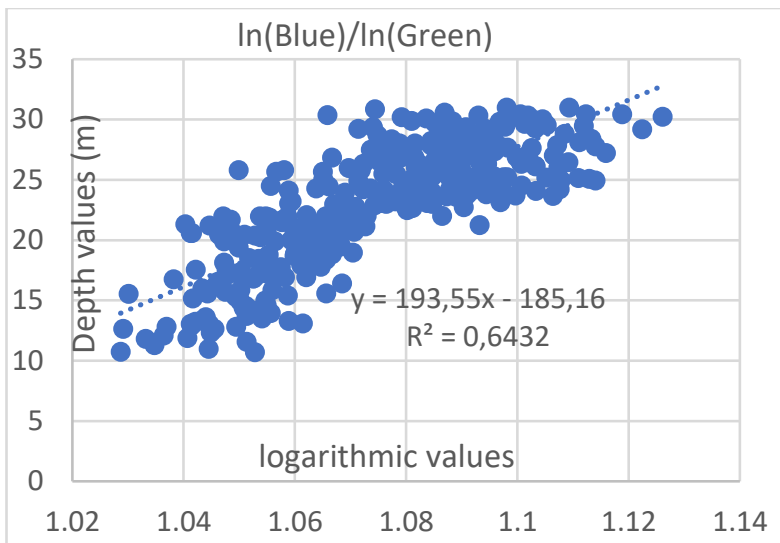

Figure 3. Band rate distribution

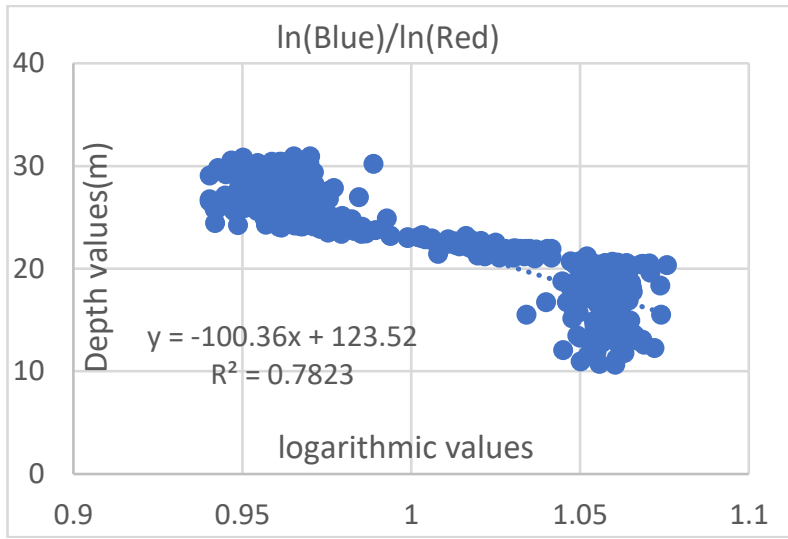

Figure 4. Band rate distribution

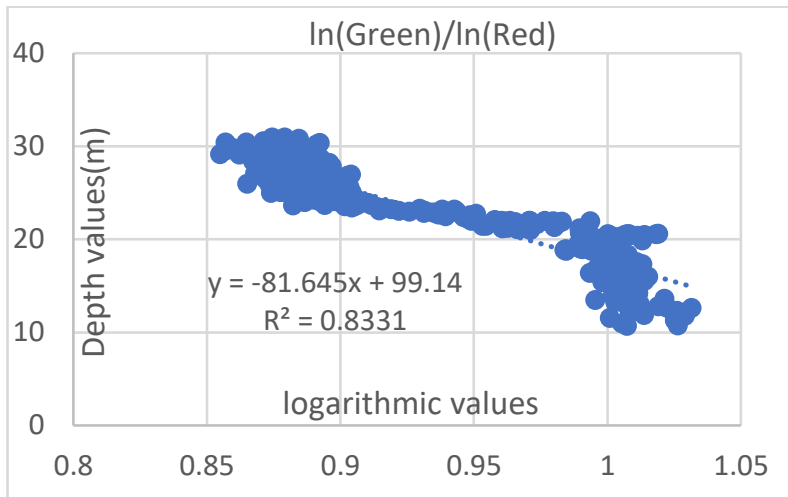

Figure 5. Band rate distribution

As shown in Figures 3, 4, 5, the (blue) / In (green) band ratio values fit better along the regression line compared to the other graphs. In In (blue) / ln (red) and ln (green) / ln (red) band combinations, scattering from the regression line is observed in regions with a depth of 10 to 15 meters and 25 to 30 meters. The factors causing these scattering are the fact that the red spectral band has more absorption in the water column than the other bands, resulting in a narrower spectral reflection values. This narrow spectral reflection range is thought to cause scattering in the regression line in combinations with the red band.

Using the coefficients calculated by regression analysis, Equation 2 and Equation 3 depth estimation was made at points of unknown depth. 


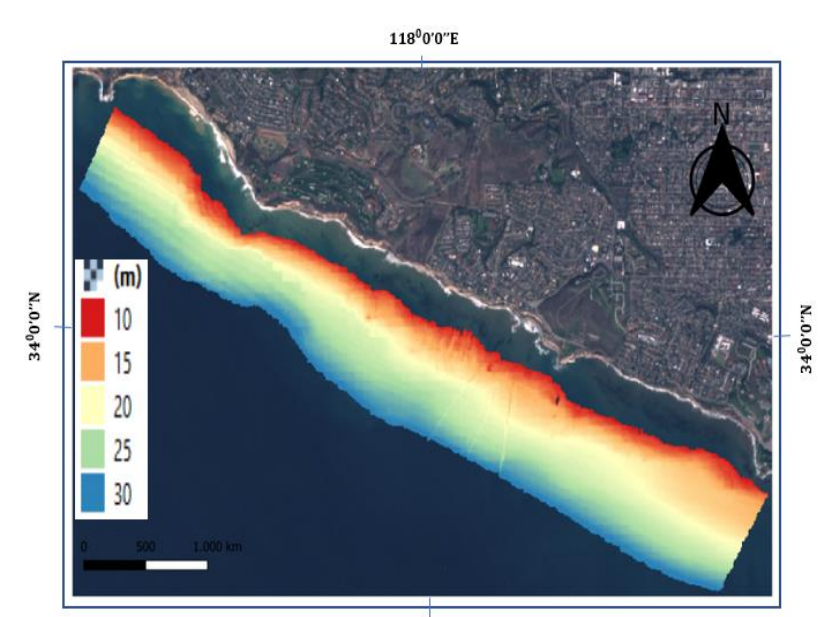

$118^{0} 0^{\prime} 0^{\prime \prime} \mathrm{E}$

Figure 6. Reference bathymetry map of the study area

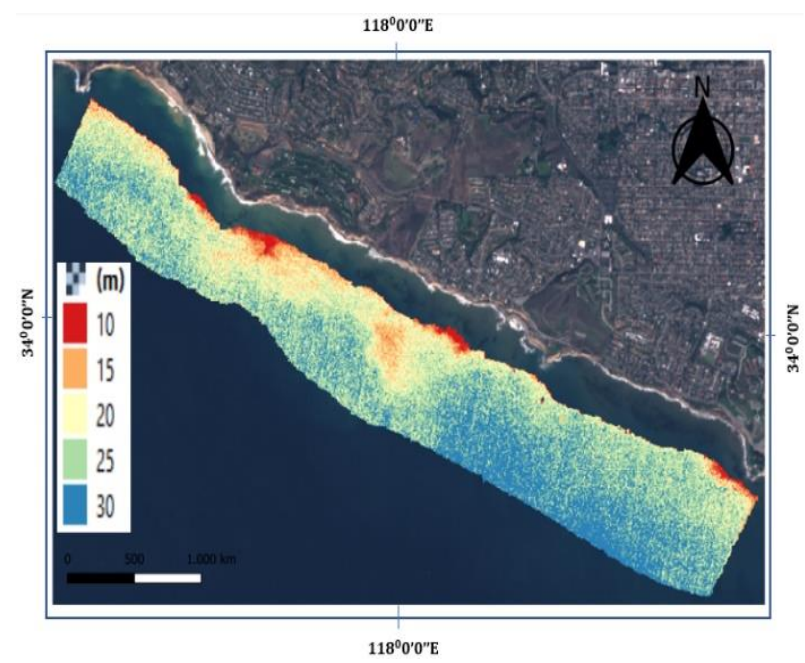

Figure 7. In (blue) / ln (green) forecast bathymetry map

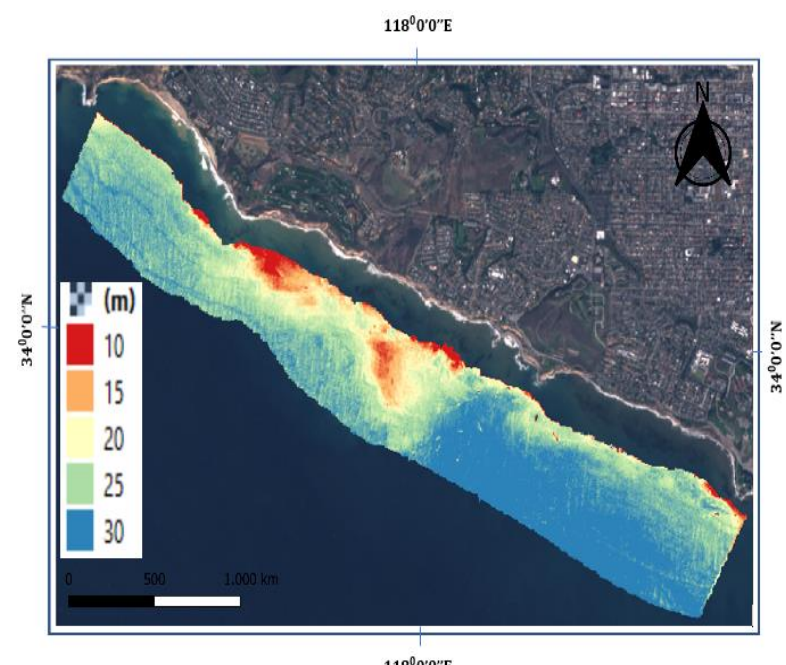

Figure 8. $\ln$ (green) $+\ln$ (blue) $+\ln$ (red) forecast bathymetry map

It has been observed that the estimated bathymetry maps generally have values close to each other. The best correlation was obtained from multiple regression analysis with a combination of blue, green, and red bands. The lowest correlation was calculated from the ratio of the blue band to the green band. The error from the blue, green and red band combination with the best correlation is higher than the error from the ratio of the blue band to the green band with the lowest correlation (Table 2). The reason for this error is the changes in the spectral reflection of the red band associated with the water column.

Table 2. Correlation and error of band groups

\begin{tabular}{|c|c|c|c|c|c|}
\hline \multicolumn{6}{|c|}{ Models } \\
\hline \multicolumn{4}{|c|}{$\begin{array}{l}\text { Dual band ratio } \\
\text { method }\end{array}$} & \multicolumn{2}{|c|}{$\begin{array}{l}\text { Multi band } \\
\text { method }\end{array}$} \\
\hline & $\begin{array}{l}\ln \text { (blue)/ } \\
\ln \text { (green) }\end{array}$ & $\begin{array}{l}\ln \text { (blue/l } \\
\ln \text { (red) }\end{array}$ & $\begin{array}{l}\text { n(green) } \\
\text { n(red) }\end{array}$ & $\left\{\begin{array}{l}\text { n(blue)+ } \\
\text { n(green) }\end{array}\right.$ & $\begin{array}{l}\ln \text { (blue)+ } \\
\ln \text { (green)+ } \\
\ln \text { (red) }\end{array}$ \\
\hline Correlation & 0.802 & 0.884 & 0.913 & 0.966 & 0.968 \\
\hline $\begin{array}{l}\text { Absolute } \\
\text { error(m) }\end{array}$ & 5.364 & 5.429 & 5.431 & 5.607 & 5.951 \\
\hline $\begin{array}{l}\text { Relative } \\
\text { error(\%) }\end{array}$ & 30.199 & 32.883 & 32.233 & 32.913 & 34.669 \\
\hline RMSE(m) & 6.565 & 6.835 & 6.722 & 6.909 & 7.305 \\
\hline
\end{tabular}

\section{DISCUSSION AND CONCLUSIONS}

This study demonstrates the potential of Sentinel-2 satellite images to predict bathymetry at $10 \mathrm{~m}$ spatial resolution for Los Angeles coastal regions in low turbidity conditions. Analyzes made with Sonar and LIDAR systems are restricted in terms of time and cost. However, bathymetry studies made with satellite images were much less affected by time and cost as in this study. In addition, it has been seen that it has a greater potential than others in terms of repeatability and analysis of large areas compared to other analysis methods. Bathymery products derived from satellites can be obtained in both models. In the study, it was seen that the methods used did not adapt well due to the greater absorption of sunlight in the regions around $25 \mathrm{~m}$. Several researchers report that the methods are successful in shallow water areas of about $15 \mathrm{~m}$ (Kerr \& Purkis, 2018). When evaluating the accuracy of the methods used in the study depending on seasonal effects, the amount of chlorophyll in the water and the turbidity of the water are the most important factors affecting the accuracy of the study. Because the methods show better results in clear shallow water. In a study, the relationship of chlorophyll amounts with the seasons over the years was examined and it was determined that the amount of chlorophyll changed according to the season (Liu \& Wang, 2013).

The red band at $665 \mathrm{~nm}$ (B04) has a narrow reflection range as a result of its interaction in the water column. This caused more scattering than other band combinations (Figure 9.) in regions with 
depths of $10 \mathrm{~m}$ and $15 \mathrm{~m}$ and $25 \mathrm{~m}$ and $30 \mathrm{~m}$, resulting in outliers.

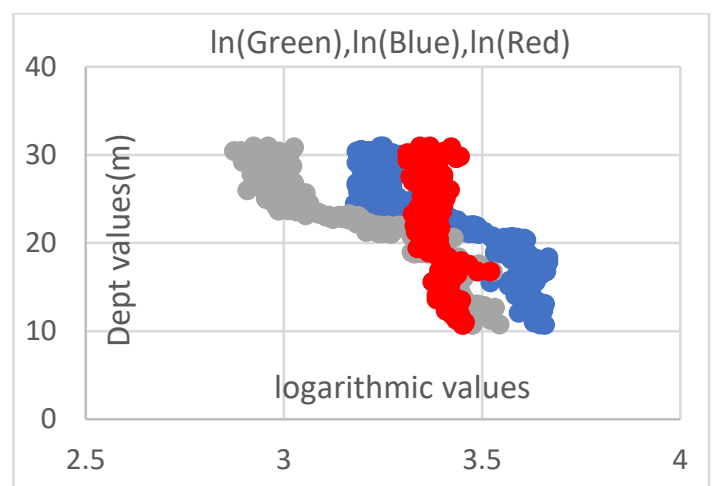

Figure 9. Logarithmic reflections of blue, green, red bands.

Bathymetry data derived from satellites can be used as reference data in remote areas, hard-toreach areas or areas not drilled. Therefore, bathymetry can be considered as a potential technology in areas where research is not conducted or is insufficient.

In this study, Sentinel-2 demonstrates the ability to produce bathymetric maps with $10 \mathrm{~m}$ resolution with satellite images. The methods showed satisfactory results in shallow and less turbid waters. In the band ratio method, the ratio of blue band to green band gave healthier results compared to other band combinations. In band combinations with red band, it has been observed that the interaction of the red band with the water column causes more errors than the other combinations. Work may include to investigate the methods with use of higher resolution datasets.

\section{ACKNOWLEDMENT}

This work has been supported by General Directorate of Mapping Turkey. Authors acknowledge the datasets provided by Sentinel Copernicus and TCARTA.

\section{REFERENCES}

Agency, European Space. (2015). Sentinel-2 User Handbook. Paris: ESA.

Bailly du Bois, P. (2011). Automatic calculation of bathymetry for coastal hydrodynamic models. Computers \& Geosciences, 13031310.

Bramante, J. F., Raju, D. K., \& Sin, T. M. (2012). Multispectral derivation of bathymetry in Singapore's shallow, turbid waters. International Journal of Remote Sensing, 34, 2070-2088.

Brando, V., Anstee, J., Wettle, M., Dekker, A., Phinn, S. \& Roelfsema, C. (2009). A physics based retrieval and quality assessment of bathymetry from suboptimal hyperspectral data. Remote Sensing of Environment, 113(4), 755-770.

Brock, J., Wright, C., Clayton, T. \& Nayegandhi , A. (2004). LIDAR optical rugosity of coral reefs in Biscayne National Park, Florida. Coral Reefs, 23(1), 48-59.

Caballero, I. \& Stumpf, P. R. (2019). Retrieval of nearshore bathymetry from Sentinel-2A and 2B satellites in South Florida coastal waters. Estuarine, Coastal and Shelf Science, 226, 106-277.

Chen, B., Yang, Y., Xu, D. \& Huang, E. (2019). A dual band algorithm for shallow water depth retrieval from high spatial resolution imagery with no ground truth. ISPRS Journal of Photogrammetry and Remote Sensing, 151, 1-13.

Costa, B., Battista, T. \& Pittman, S. (2009). Comparative evaluation of airborne LiDAR and ship-based multibeam SoNAR bathymetry and intensity for mapping coral reef ecosystems. Remote Sensing of Environment, 113(5), 1082-1100.

Dartnell, P. \& Gardner, J. (2004). Predicting seafloor facies from multibeam bathymetry and backscatter data. Photogrammetric Engineering and Remote Sensing, 70(9), 1081-1091.

Gao, J. (2009). Bathymetric mapping by means of remote sensing: Methods, accuracy and limitations. Progsress in Physical Geography, 103-116.

Gitelson, A., Kaufman, Y. \& Merzlyak, M. (1996). Use of a green channel in remote sensing of global vegetation from EOS- MODIS. Remote Sensing of Environment, 58(3), 289-298.

Jawak, S. D. \& Luis, A. J. (2015). Spectral Information Analysis for the Semiautomatic Derivation of Shallow Lake Bathymetry Using Highresolution Multispectral Imagery: A Case Study of Antarctic Coastal Oasis. Aquatic Procedia, 4, 1331-1338.

Kerr, J. M. \& Purkis, S. (2018). An algorithm for optically-deriving water depth from multispectral imagery in coral reef landscapes in the absence of ground-truth data. Remote Sensing of Environment, 210, 307-324.

Kumari, P. \& Ramesh, H. (2020). Remote sensing image based nearshore bathymetry extraction of Mangaluru coast for planning coastal reservoir. Sustainable Water Resource Development Using Coastal Reservoirs, 247-265.

Lee, Z., Carder, K., Mobley, C., Steward, R. \& Patch, J. (1999). Hyperspectral remote sensing for shallow waters: 2 . Deriving bottom depths and water properties by optimization. Applied Optics, 38(18), 3831-3843.

Liu, D. \& Wang, Y. (2013). Trends of satellite derived chlorophyll-a (1997-2011) in the Bohai and 
Yellow Seas, China: Effects of bathymetry on seasonal and inter-annual patterns. Progress in Oceanography, 116, 154-166.

Liu, S., Gao, Y., Zheng, W. \& Li, X. (2015). Performance of two neural network models in bathymetry. Remote Sensing Letters, 6(4), 321-330.

Ma, M., Wang, X. \& Veroustraete, F. (2007). Change in area of Ebinur Lake during the 1998-2005 period. International Journal of Remote Sensing, 28(24), 5523-5533.

Maritorena, S., Morel, A. \& Gentili, B. (1994). Diffuse reflectance of oceanic shallow waters: Influence of water depth and bottom albedo. Limnology and Oceanography, 39(7), 16891703.

Misra, A. \& Ramakrishnan, B. (2020). Assessment of coastal geomorphological changes using multi-temporal Satellite-Derived Bathymetry. Continental Shelf Research, 207.

Pacheco, A., Horta, J., Loureiro, C. \& Ferreira, Ó. (2015). Retrieval of nearshore bathymetry from Landsat 8 images: A tool for coastal monitoring in shallow waters. Remote Sensing of Environment, 102-116.
Philpot, W. (1989). Bathymetric mapping with passive multispectral imagery. Applied Optics, 28(8), 1569-1578.

Stumpf, P. R., Holderied, K., \& Sinclair, M. (2003). Determination of water depth with highresolution satellite imagery over variablebottom types. Limnol. Oceanog, 48(1), 547-556.

Wilson, M. F., O'Connell, B., Brown, C., Guinan, J. \& Grehan, A. (2006). Multiscale Terrain Analysis of Multibeam Bathymetry Data for Habitat Mapping on the Continental Slope. Marine Geodesy, 3-35. 